\title{
SOCIAL LEARNING APPROACH TO ADOLESCENT MOTHERS IN EAST JAVA, INDONESIA
}

\author{
Wahidah Inayatul*, Wardhana Icchami Tasya \\ Department of Industrial \& Organizational Psychology, Faculty of Psychology, \\ Airlangga University, Indonesia \\ *E-mail: inayatulwahidah@gmail.com
}

\begin{abstract}
In Indonesia, early marriage becomes one of the serious problems, this happens both in the city and in the village with different social, economic, and cultural backgrounds. According to the results of research conducted by the United Nations Children Fund (UNICEF), one of the six girls in Indonesia was married before the age of 18 years. The numbers 340,000 children per year, as for the under 15 years to reach 50,000 children per year. The United National Development Economic and Social Affairs (UNDESA) puts Indonesia at the 37th in the world ranked and ranked 2nd in ASEAN as one country with the high early marriage. Early marriage can lead to negative effects on education, socio-economic, demographic, psychological, and health. Members of these families in early marriage are struggling with troubling relationships and difficulties in carrying out their family responsibilities. This study aims to determine how the social learning approach could be a valuable approach to helping them gain new skills and address their belief systems. It can help them develop a critical sense of mastery and self-efficacy and begin to replace their current dysfunctional belief systems with those that can be more productive within the family. The method used in this research is the qualitative method. Participants in this research are adolescent mothers that will provide answers regarding the concept of social learning they understand. Data collected by interview and analyzed using the thematic analysis technique. Results of an initial interview about the concept of social learning that can improve effective learning opportunities that enable family members to learn and implement new coping skills. Family members might need skills, for example, in communicating, in parenting, in dealing with other community members, in addressing employment issues.
\end{abstract}

\section{KEY WORDS}

Social learning, early marriage, adolescent, East Java.

Based on data from the National Economic Survey (Susenas) in 2012 showed that East Java province ranked 3rd in Indonesia for the prevalence of marriage among girls (15 19 years). In East Java, the provincial prevalence in this age range, at 16,7\%, whereas the district is between $5 \%$ to $35 \%$ and the sub-districts ranged from $2 \%$ to $64 \%$. The districts with the highest prevalence (Bondowoso about 35\%, Probolinggo about 35\%, Situbondo about $34 \%$, and Sumenep about $32 \%$ ) have sub-districts with high prevalence, such as Sumbermalang in Probolingggo about 64\%. However, the second-highest prevalence in the district at Esat Java (Lumbang about 63\%) is located in Pasuruan, which is the district with a lower prevalence of about $19 \%$.

The marriage age of the teen to a certain extent is also considered a legal marriage in Indonesia. The petition for judicial review of article 7 of the law of marriage in Indonesia (1974) concerning the minimum age of marriage has caused intense debate in Indonesia. According to the current law of marriage in Indonesia, parental consent may be filed to support all marriage protocols under the age of 21 years. With the consent of parents, girls can legally marry at 16 years and boys at age 19 years. However, the parents of girls aged under 16 years can marry off their daughters while still very young to apply to the marriage officer or the district court to grant a dispensation (Sitepu \& Melissa, 2015). However, the judicial review was rejected by the Constitutional Court on 18 June 2015. The Constitutional Court ruled that the change in the age of marriage is the authority of the House of 
Respentatives (Middleton, 2015).

Marriage at a young age can interfere with the developmental stages of adolescent life, who should be a time for the development of physical, emotional, and social development. Adolescence is also very important for them because this is the period in which they can prepare themselves for adulthood (Plan International, 2012). Various studies have shown that girls who marry at an early age have a higher risk for anxiety, depression, or have thoughts of suicide, one of the factors that encourage the occurrence of such things because they do not have status, power, support, and control over their own lives (Gage, 2013). Other studies also show that a girl who married at a young age has a greater chance of experiencing physical, sexual, psychological, and emotional, and social isolation, which is a result of their lack of status and power within their household.

Despite the marriage age of teens is an important issue in Indonesia, but the level of acceptance and practice of teen marriage age varies throughout the country geographically, culture, and religion. The age of marriage is influenced by custom or local beliefs and religion. For example, in some areas in Indonesia, local customs have caused many daughters to marry a much older man. However, research also shows that some teens choose to get married on the desire of their parents because of the stigma about women who are not married, fear of pregnancy or the introduction of premarital sex, and poverty. Therefore, the practice of teen marriage age in Indonesia is complex and reflects the diversity of values and social norms in Indonesia.

Members of these families in early marriage are struggling with troubling relationships and difficulties in carrying out their family responsibilities. The social learning approach is essentially an optimistic and strengths-based approach that assumes people are able to learn. The current patterns that one sees in families can be understood in terms of the family members' past and present learning opportunities. The central approach within a social perspective is to provide effective learning opportunities that enable family members to learn and implement new coping skills. Family members might need skills, for example, in communicating, in parenting, in dealing with other community members, in addressing employment issues.

Bandura and colleagues identify how current behavior is not only shaped by the actual reinforcement but also by social context and cognitions, especially the person's expectations for such responses (Bandura, 1977, 1978). Cultural and unique individual life experiences shape relevant beliefs, learning opportunities, and anticipated rewards. Expectations regarding the impact of behavior are critical in the actual performance of the behavior. If people believe that they are able to carry out a specific behavior (self-efficacy) and will be positively rewarded for this behavior, they are more likely to act in this manner. High selfefficacy will improve the performance of a person in many ways. A person with high selfefficacy assumes difficult tasks as challenges to be mastered rather than as threats to be avoided. They set themselves challenging goals and maintain commitment. In the face of failure, they can maintain their efforts and quickly restore their confidence towards success (Bandura, 1994).

Bandura defines self-efficacy as people's beliefs about their capabilities to produce designated levels of performance that exercise influence over events that affect their lives. Self-efficacy beliefs determine how people feel, think, motivate themselves, and behave. Such beliefs produce these diverse effects through four major processes. They include cognitive, motivational, affective, and selection processes (Bandura, 1994 in Ramachaudran, 198). Bandura (1997) also indicated that self-efficacy influences resistance to adversity and helps avoid stress and depression in difficult conditions.

Bandura (1997) states that there are 3 dimensions of self-efficacy, namely:

- Magnitude, is the dimension of self-efficacy which refers to the degree of difficulty of the task that a person believed to be completed. A person with high magnitude selfefficacy will be able to complete a difficult task. While a person with low magnitude self-efficacy would only able to carry out the simple one.

- Strength, refers to a person who has high self-efficacy will remain in the face of obstacles and problems. While a person with low strength self-efficacy will be more 
easily frustrated when faced with obstacles or problems in completing tasks.

- Generally, the dimensions of self-efficacy which refers to the degree of perfection of self-efficacy in certain situations. Some people are able to adapt to various conditions. But there is also a person who believes that they are only able to perform some specific behavior in certain circumstances.

\section{METHODS OF RESEARCH}

The present study used descriptive phenomenology (Husserl, 1913/1962; Porter, 1998). The purpose of phenomenology is to illuminate the specific, to identify phenomena through how they are perceived by the participant in a situation (Lester, 1999). Husserl stated that we can only know what experience by tending to perceptions and meanings that awaken our conscious awareness (Patton, 2002). In so doing, it is thought that the researcher is able to capture a participant's consciousness of the phenomenon of interest (i.e., phenomena of being a married woman between 15 and 19 years). Methodological guidelines and analysis techniques of descriptive phenomenology developed by Porter (1998; Sharp Ganong, 2011) produce two distinct aspects of the phenomena of interest, (a) lived experience and (b) lifeworld context, which is the focus of the present study. Lived experience data reflect what the participant thinks about and "does" (intentions) with the experience. Lifeworld context refers to data reflecting participants' perceptions of their social environment, including both micro and macro levels. For example, family members, friends, and coworkers' comments, reactions, and behaviors, as well as broader messages/assumptions in culture (e.g., media, holidays) about early marriage, are all considered life-world context data.

Participants in this study were selected through the characteristic of participants that we discussed in the background section. Study criteria included a woman who experienced early marriage, aged 15 to 19 years, this age limit is categorized as early marriage because according to Indonesian law, women are recognized as legally married by the age of 21 years. Had children and the role of being a mother and their home town from East Java region. Detailed demographic information of these participants is listed in Table 1.

The first author conducted 8 interviews (i.e., two interviews with four participants) over 1 month after the primary researcher contacted each of them to explain the purpose of the study and asked them to participate in telephone interviews. The interview lasted between 35 and 60 minutes. The counseling process was conducted after we got all the required data through interviews within 2 weeks. All participants were asked questions along with three general themes: "Tell me about your reason for married at a young age", "What is your viewpoint being a young mother", and "How do you confront obstacles and your future expectations in your married life". Data interviews were audio-recorded with the permission of the participants.

The interviews were transcribed verbatim for each participant. Since the interviews were done in the Indonesian language, the entire interview was transcribed in Indonesian. Following a first reading of the transcripts, the second round of careful reading extracted a list of invariant expressions. An invariant expression is a few words that are necessary and sufficient to constituent a category that is understandable for understanding (Moustakas, 1994; Wang \& Abbott, 2013). Finally, the meanings of these expressions and statements were generated in Indonesian before being translated into English. By placing all the statements back into the conversation contexts, the researchers were able to clearly understand the meanings of the statements. Participants' expressions were organized into themes that were broader and had more general categories. Final validation was done by having the respondents read the themes and comment on their accuracy (Creswell, 1998). All four participants stated that the themes represented the essence of their experiences. Three major themes arising from the analysis, (1), value and reason of early marriage; (2) the viewpoint of being a mother at a young age; and (3) self-efficacy and expectations of the future. 


\section{RESULTS OF STUDY}

The interviews were transcribed verbatim for each participant. Since the interviews were done in the Indonesian language, the entire interview was transcribed in Indonesian. Following a first reading of the transcripts, the second round of careful reading extracted a list of invariant expressions. An invariant expression is a few words that are necessary and sufficient to constituent a category that is understandable for understanding (Moustakas, 1994). Finally, the meanings of these expressions and statements were generated in Indonesian before being translated into English. By placing all the statements back into the conversation contexts, the researchers were able to clearly understand the meanings of the statements (see Table 2 for an example of how this was done). After the themes were identified, the researchers referred back to the original transcripts to check for accuracy. Final validation was done by having the respondents read the themes and comment on their accuracy (Creswell, 1998). All four participants stated that the themes represented the essence of their experiences.

Table 1 - Demographic information of participants

\begin{tabular}{lllllll}
\hline Participants & Age & Age when married & Education Level & Occupation & Hometown & Number of children \\
\hline RU & 18 & 17 & Senior High School & Housewife & Probolinggo & 1 \\
\hline SD & 21 & 18 & Elementary School & Housewife & Situbondo & 1 \\
\hline TA & 19 & 18 & Senior High School & Housewife & Bondowoso & 1 \\
\hline MM & 18 & 18 & Senior High School & Housewife & Situbondo & 1 \\
\hline
\end{tabular}

Three major themes arising from the analysis, (1) The value and the reason of married at a young age; (2) The viewpoint of being a mother at a young age; (3) Self-efficacy and expectations of the future.

Each subject has different reasons for their early marriage. Participant RU said that the reason married at a young age because it was a shotgun marriage. While Participant SD explained that she offered an arranged marriage by her parents. Participant TA and MM equally explain the reason is that they are already proposed and without any coercion from others. Related to their value in early marriage, they can express their value about their marriage. Participant $R U$ explained his value:

'Mmm marriage means having a family. That is, do not know what to say anymore.'

SD who since childhood has to be left to his parents and used to live abroad, explain that she did not understand and feel it is a usual thing. So is participant TA. In contrast to both of them, Participant MM stated that early marriage is an exciting experience. She explained her value:

'Wow an early marriage is very exciting, at an early age I have been given the opportunity to take care of my husband, learn responsibility, plus raising children.'

Only participant RU expresses dissatisfaction with her youth, she is still regarded her age as a period of freedom, free to hang out with her friends.

'I am still not satisfied, I actually want to freely socialize with my friends, but how else, I already forced to married at a young age.'

In contrast to RU, SD feels that her dream is reached after she got married. Participant SD revealed that she wants to have her own house. While participant TA and MM revealing that they have dreams for higher education, but because it has been decided to get married they think it would be difficult to do so.

Related to the viewpoint becomes a mother at a young age, all the participant does not have a clear view. But they explain what they feel at the moment. Participant RU said:

'at that time, I thought that I love my boyfriend, so we have done sex before we married, but after that I regretted it. I did not think about the consequences later, but how else, yes we did that.'

Even participant $\mathrm{RU}$ thought about abortion when she realized her pregnancy, but the plan did not work because the family already knows the condition of her pregnancy.

'In the beginning, I knew I was pregnant, I thought the solution to this problem was to 
abort, but it didn't work. Not long after that my parents also aware of my pregnancy. I am their daughter; after all, my parents began to worry about my pregnancy. My mother asked me directly but because of fear, I can't be honest with her, my mother asked my neighbor to asked me about my current state. I'm an over-sensitive person, so when they asked me, I cried directly. Well after that, $\mathrm{mm}$ they suggested to check up, it turns out that I was 3 months pregnant.'

Table 2 - Counseling process with social learning approach

\begin{tabular}{|c|c|c|c|c|}
\hline Participant & $\begin{array}{l}\text { Purpose/ } \\
\text { Goal }\end{array}$ & $\begin{array}{l}\text { Time } \\
\text { \&Setting }\end{array}$ & Result & Evaluation \\
\hline $\mathrm{RU}$ & $\begin{array}{l}\text { Help } \\
\text { family } \\
\text { members } \\
\text { identify } \\
\text { and } \\
\text { counter } \\
\text { destructive } \\
\text { cognitions }\end{array}$ & $\begin{array}{l}3 \text { November } \\
2019 \\
\text { Psychology } \\
\text { Lab UNAIR }\end{array}$ & $\begin{array}{l}\text { Helping Participant RU } \\
\text { recognize that "doing } \\
\text { something because the } \\
\text { other person asked for it } \\
\text { can be a sign of caring" } \\
\text { might be another way of } \\
\text { interpreting this new } \\
\text { behavior that furthers the } \\
\text { healing process. }\end{array}$ & $\begin{array}{l}\text { The family can also help in creating } \\
\text { these changes. RU's parents might be } \\
\text { encouraged to phrase their help in ways } \\
\text { that can be less threatening to RU. } \\
\text { Sharing with her their uncertainty and } \\
\text { fears when they were new parents might } \\
\text { reduce her thoughts that she is being } \\
\text { criticized. They can also comment } \\
\text { favorably on things that she is doing in } \\
\text { her care of the baby. }\end{array}$ \\
\hline SD & $\begin{array}{l}\text { Help } \\
\text { families } \\
\text { reinforce } \\
\text { positive } \\
\text { behavior } \\
\text { meaningful } \\
\text { for } \\
\text { individuals } \\
\text { involved }\end{array}$ & $\begin{array}{l}7 \text { November } \\
2019 \\
\text { Psychology } \\
\text { Lab UNAIR }\end{array}$ & $\begin{array}{l}\text { Participant SD lacks role } \\
\text { models who have given } \\
\text { affirmation; therefore the } \\
\text { counselor can serve as a } \\
\text { role model for such } \\
\text { behavior. The counselor } \\
\text { then problem-solves with } \\
\text { family members about the } \\
\text { reinforcements that would } \\
\text { be meaningful and feasible } \\
\text { within this family context } \\
\text { and the ways to implement } \\
\text { them in the life of the } \\
\text { family. }\end{array}$ & $\begin{array}{l}\text { If Participant SD does not believe } \\
\text { (expectancies) that their positive } \\
\text { changes will be favorably recognized } \\
\text { (positive reinforcement), they will be less } \\
\text { likely to continue these behaviors and to } \\
\text { make them part of the life of the family. }\end{array}$ \\
\hline TA & $\begin{array}{l}\text { Help } \\
\text { family } \\
\text { members } \\
\text { develop } \\
\text { needed } \\
\text { new skills }\end{array}$ & $\begin{array}{l}15 \\
\text { November } \\
2019 \\
\text { Psychology } \\
\text { Lab UNAIR }\end{array}$ & $\begin{array}{l}\text { Identification important skill } \\
\text { that can be useful in the } \\
\text { future. } \\
\text { Counselors give feedback } \\
\text { about ways to improve their } \\
\text { skills. }\end{array}$ & $\begin{array}{l}\text { Family members might lack the skills to } \\
\text { carry out this positive change. As a } \\
\text { result, they will need help in learning and } \\
\text { carrying out these new behaviors. The } \\
\text { family counselor can use the family } \\
\text { session to model the new behaviors and } \\
\text { to enable family members to practice } \\
\text { them. }\end{array}$ \\
\hline MM & $\begin{array}{l}\text { Educate } \\
\text { the family } \\
\text { about the } \\
\text { learning } \\
\text { process }\end{array}$ & $\begin{array}{l}17 \\
\text { November } \\
2019 \\
\text { Psychology } \\
\text { Lab UNAIR }\end{array}$ & $\begin{array}{l}\text { Participant TA can } \\
\text { understand their family and } \\
\text { to make additional positive } \\
\text { changes in other areas and } \\
\text { in the future. }\end{array}$ & $\begin{array}{l}\text { Helping family members learn about } \\
\text { ways in which behavior is learned and } \\
\text { reinforced can give family members the } \\
\text { tools to understand their family. }\end{array}$ \\
\hline
\end{tabular}

In contrast to RU Participant, SD, MM and TA expressed their gratitude to have children and become a mother at a young age.

Participant $R U$ and $S D$, both feel the need to receive help or advice from others as long as it is not excessive and does not make them still look like a child.

To successfully through the stages of being a parent, it takes a commitment to time as a parent, understanding the role as a parent, and adaptation to the development of changes in child development (Santrock, 1996). Problems often arise when someone for the first time being a parent is in disagreement over responsibility, as well as the refusal or inability to function as a capable parent for their children (Santrock, 1996).

Participant RU and SD, both are capable of completing tasks that are considered difficult as a young mother because both have high acceptance concepts. Although their description of the pressures and challenges are different, both explain that they overcome the difficulties with more accepting of the situation and live out what had happened. 
Participant RU said:

'lots to do, from bathing my son, feeding him, breastfeeding, not to mention clean the house, take care of my husband as well. Yes, everything should be done.'

And participant SD said:

'I used to go where ever I want to go, that freedom before I got married, not like now to bother carrying children, I must have my husband's permission if I want to go out of the house, and of course bring along my son. I also do housework, cooking, cleaning the house. My husband assisted me as well, yes he sometimes bathing our son, put the child in bed, cleaning the house.'

With the ability to withstand problems, SD relatively more resilient than $R U$. This is evident from the statement from SD, she said:

'The burden more and more, at the first we do not have children, now we are three, and I must take care of both of them and including myself. But I do not feel overwhelmed, it is an obligation that must be done by me as a wife and mother.'

While $R U$ is expressing regret and dissatisfaction pressures she felt after becoming a mother at such a young age.

'I admit I regretted it, if you ask me it feels more comfortable when I was single because I am not yet satisfied to make friends, because when I graduated from school my parent told me directly to get married as soon as possible, I have never had the opportunity to work, have not felt other things like the other teens, just so had got married at a young age.'

Related to the ability to adapt to its environment, Participant RU and SD, both said that they felt constrained in dealing with peers. This is possible because they both become a mother in adolescence, whereas in adolescence, the developmental tasks should not come to the stage of married.

\section{CONCLUSION}

The social learning approach represents opportunities that enable family members to develop more effective coping strategies and relate to each other in more positive ways. Jordan, Cobb, and Franklin (1999) reviewed the literature on family counseling derived from behavioral learning principles and found them to be effective in addressing parent-child and marital issues. Parent-child issues have also responded well to programs combining cognitive and behavior components (Jordan, Cobb, \& Franklin, 1999, p. 91). Parental education has emerged as helpful for the targeted behavior but as having less impact on other behaviors, thus suggesting limitations in generalizability (Nichols \& Schwartz, 2001). While parental education has demonstrated effectiveness in addressing conduct disorders with children, families with many risk factors show less improvement than do families with fewer risk factors. Length of treatment (especially more than ten sessions) and the therapist's knowledge of social learning principles and skills were also associated with increased effectiveness of this approach (Sexton, Robbins, Hollimon, Mease, \& Mayorga, 2003).

\section{REFERENCES}

1. Badan Pusat Statistik. (2016). Kemajuan yang tertunda: Analisis data perkawinan usia anak di Indonesia. Jakarta: Badan Pusat Statistik

2. Bandura, A. (1997). Self efficacy: The Exercise of Control. USA: W. H. Freemen and Company.

3. Bandura, A. (1994). Self-efficacy. In V. S. Ramachaudran (Ed.), Encyclopedia of human behavior (Vol. 4, pp. 71-81). New York: Academic Press. (Reprinted in H. Friedman [Ed.], Encyclopedia of mental health. San Diego: Academic Press, 1998).

4. Evenhuis and Burn, Just Married, Just a Child, p.15.

5. Gage, A.J. (2013). Association of child marriage with suicidal thoughts and attempts among adolescent girls in Ethiopia. Journal of Adolescent Health, 52, (5), p. 654

6. Jain and Kurz, New Insights on Preventing Child Marriage, p. 8; ICRW. Development 
Initiative on Supporting Health Adolescents (DISHA) Project; and Raj When the mother is a child, p. 931.

7. Jordan, C., Cobb, N. H., \& Franklin, C. (1999). Family therapy using cognitive behavioral methods. In C. Jordan, \& C. Franklin. (Eds.), Family practice: Brief systems methods for social work. Pacific Grove, CA: Brooks/Cole.

8. Lester, S. (1999). An introduction $t$ phenomenological research. Stan Lester Development: Taunton.

9. Middleton, R. (2015). Indonesia: Constitutional Court throws out petition to raise girls' minimum age to 18. IBTimes. Available from: http://www.ibtimes.co.uk/indonesiaconstitutional-court-throws-out-petition-raise-girls-minimum-marriage-age-18-1507855. Accessed 25 June 2015.

10. Nichols, M. P. \& Schwartz, R. C. (2001). Cognitive-behavioral family therapy. In M. P. Nichols \& R. C. Schwartz, Family therapy: Concepts and methods (5th ed., pp. 265305). Boston: Allyn and Bacon.

11. Patton, M. Q. (2002). Qualitative research \& evaluation methods 3rd : Sage Publication Inc

12. Plan International. (2012). Because I am a Girl: The state of the world's girls 2012: Learning for life. London: Plan International, p. 22.

13. Sexton, T. S., Robbins, M. S., Hollimon, A. S., Mease, A. L., \& Mayorga, C. C. (2003). Efficacy, effectiveness, and change mechanism in couple and family therapy. In T.L. Sexton, G. R. Weeks, \& M.S. Robbins (Eds.), Handbook of Family Therapy (pp. 229261). New York: Brunner Routledge.

14. Shap, E. A., Ganong, L. (2011).“'m a loser, I'm not married, let's just all look at me”: Ever-single women's perceptions of their social environment. Journal of Family Issues, $32(7), 956-980$.

15. Sitepu, A. and Y. Meilissa. (2015). Salvaging the Marriage Law. Jakarta: The Jakarta Post. Available from: http://www.thejakartapost.com/news/2015/06/23/salvagingmarriage-law.html. Accessed 23 June 2015.

16. Van Hook, M. P. (2014). (2nd edition) Social work practice with families: A resiliencybased approach. Chicago, IL: Lyceum.

17. Wang, H., Abbott, D. A. (2013) Waiting for Mr. right: The meaning of being a single educated Chinese female over 30 in Beijing and Guangzhou. Women's Studies International Forum, 40, 222-229.

18. WHO. (2014). World Health Statistics 2014. Geneva, Switzerland: World Health Organization. 